
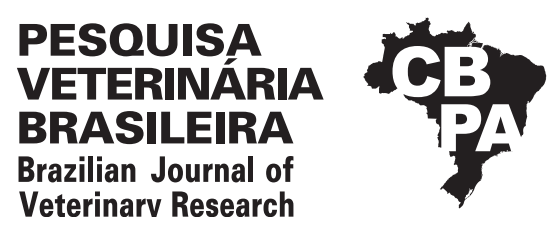

Pesq. Vet. Bras. 40(2):77-81, February 2020 DOI: $10.1590 / 1678-5150-P V B-6406$

Original Article

\title{
Epidemiological analysis of bovine tuberculosis in the southern region of Rio Grande do Sul from 2000 to $2015^{1}$
}

\author{
Taina S. Alberti ${ }^{*}$ (D), Fabio Raphael P. Bruhn ${ }^{3}$, Rosimeri Zamboni ${ }^{2}$ (D), \\ Fabiano R. Venancio ${ }^{4}$ (D), Haide Valeska Scheid ${ }^{2}$ (D), Margarida B. Raffi ${ }^{3}$, \\ Ana Lucia Schild ${ }^{5}$ (D) and Eliza Simone V. Sallis ${ }^{3}$ (D)
}

\begin{abstract}
Alberti T.S., Bruhn F.R.P., Zamboni R., Venancio F.R., Scheid H.V., Raffi M.B., Schild A.L. \& Sallis E.S.V. 2020. Epidemiological analysis of bovine tuberculosis in the southern region of Rio Grande do Sul from 2000 to 2015. Pesquisa Veterinária Brasileira 40(2):77-81. Departamento de Patologia Animal, Universidade Federal de Pelotas, Campus Universitário s/n, Capão do Leão, RS 96010-900, Brazil. E-mail: taina_alberti@yahoo.com

Bovine tuberculosis (BTB) is an infectious and zoonotic disease with socioeconomic importance, responsible for economic losses in livestock due to the decrease in animal productivity, mortality, bovine carcass condemnation and restriction on exportations. The objective of the present study was to evaluate the epidemiological aspects of this disease through a descriptive analysis and time series of cases of bovine tuberculosis diagnosed at the Laboratório Regional de Diagnóstico (LRD) of the Faculdade de Medicina Veterinária, Universidade Federal de Pelotas (UFPel) from 2000 to 2015. A survey was carried out in the LRD database of cases diagnosed as tuberculosis in cattle during this period. The incidence rate of BTB ([cases/population] x 100000) was calculated. Qualitative variables (sex, age, race, origin, type of material and presumptive diagnosis) were analyzed in a descriptive way, aiming to establish the profile of affected animals, characterize the municipalities in which the disease is originated and also fix the main referral organs for diagnosis. The time series analysis was performed using the Gretl statistical software 1.9.12 (GNU Regression, Econometric and Time-series Library). To verify the existence of the stationary distribution, the test of Dickey-Fuller was used, considering a value of $p<0.05$. During this period, 331 cases of BTB were diagnosed in the LRD. The present study identified that the predominant profile of the bovines affected by tuberculosis was female bovine aged more than two years old and crossbreed; the main organ sent for histopathological examination was lymph nodes. The microregion of Pelotas presented the highest incidence of the disease. There was also a tendency of a decrease in the incidence rate of this disease over the years, absence of seasonal influence in the occurrence of the disease and no cases of epidemics occurred from 2002 to 2015 in the area covered by the LRD-UFPel.
\end{abstract}

INDEX TERMS: Epidemiology, bovine tuberculosis, Rio Grande do Sul, Mycobacterium spp., cattle, tuberculosis, post mortem inspection, histopathological examination.

\footnotetext{
${ }^{1}$ Received on July 22, 2019.

Accepted for publication on September 15, 2019.

${ }^{2}$ Graduate Program in Veterinary, Faculdade de Veterinária, Universidade Federal de Pelotas (UFPel), Campus Capão do Leão s/n, Capão do Leão, RS 96015-560, Brazil. *Corresponding author: taina_alberti@yahoo.com

${ }^{3}$ Associate Professor, Faculdade de Veterinária, Universidade Federal de Pelotas (UFPel), Campus Capão do Leão s/n, Capão do Leão, RS 96015-560.

${ }^{4}$ Residency Program in Multiprofessional and Professional Area of Health in Animal Pathology, Departamento de Patologia Animal, Universidade Federal de Pelotas (UFPel), Campus Capão do Leão s/n, Capão do Leão, RS 96015-560.

${ }^{5}$ Veterinarian, Laboratório Regional de Diagnóstico (LRD), Universidade Federal de Pelotas (UFPel), Campus Capão do Leão s/n, Capão do Leão, RS 96010-900.
}

RESUMO.- [Análise epidemiológica da tuberculose bovina na região sul do Rio Grande do Sul no período de 2000 a 2015.] Tuberculose bovina é uma enfermidade infectocontagiosa e zoonótica, de importância socioeconômica, responsável por prejuízos econômicos na pecuária em decorrência da diminuição na produtividade animal, mortalidades, condenações de carcaças e restrições nas exportações. 0 objetivo do presente estudo foi avaliar os aspectos epidemiológicos, por meio de uma análise descritiva e de séries temporais, dos casos de tuberculose bovina diagnosticados no Laboratório Regional 
de Diagnóstico da Faculdade de Veterinária, Universidade Federal de Pelotas (LRD-UFPel), no período de 2000 a 2015. Foi realizado um levantamento no banco de dados do LRD dos casos diagnosticados como tuberculose em bovinos, entre os anos de 2000 e 2015. Foi calculada a taxa de incidência da tuberculose bovina ([casos/população] x 100000). As variáveis qualitativas (sexo, idade, raça, procedência, tipo de material e diagnóstico presuntivo) foram analisadas de forma descritiva, tendo como finalidade estabelecer o perfil dos animais acometidos, caracterizar os municípios de origem, e estabelecer os principais órgãos remetidos para diagnóstico. A análise de série temporal foi feita através do software estatístico Gretl 1.9.12 (GNU Regression, Econometricand Time-series Library) e para verificar a existência da estacionariedade utilizou-se o teste de Dickey-Fuller aumentado, considerando um valor de $\mathrm{p}<0,05$. Durante este período foram diagnosticados 331 casos de tuberculose bovina no LRD. 0 presente estudo permitiu concluir que o perfil predominante dos bovinos acometidos por tuberculose foi de fêmeas, com mais de dois anos de idade e mestiças; o principal órgão encaminhado para exame histopatológico foram linfonodos e a microrregião de Pelotas apresentou a maior incidência da doença. Foi constatada, ainda, uma tendência de queda na taxa de incidência da doença ao longo dos anos analisados, ausência de influência sazonal na ocorrência da enfermidade e, não foram registrados casos de epidemias nos anos de 2002 a 2015, na área de abrangência do LRD-UFPel.

TERMOS DE INDEXAC̄̃̃O: Epidemiologia, tuberculose bovina, Rio Grande do Sul, Mycobacterium spp., bovinos, inspeção post mortem, série temporal, zoonose.

\section{INTRODUCTION}

Bovine tuberculosis (BTB) is an infectious and zoonotic disease caused by Mycobacterium bovis, a highly pathogenic bacterium for cattle and humans (López 2013). The disease is characterized by the progressive development of nodular lesions, called "tubers", in any organ or tissue (Riet-Correa \& Garcia 2007). In livestock, this disease is responsible for significant economic losses due to the decrease in animal productivity and owing to interfere in the trade in animals and related products (Perez et al. 2002, Rocha et al. 2012).

BTB is a common disease that poses a public health risk, mainly in developing countries (Humblet et al. 2009). It is estimated that $5 \%$ to $10 \%$ of human tuberculosis cases are caused by M. bovis (Prasad et al. 2005, Schiller et al. 2011, Rocha et al. 2012). Consumption of raw milk and dairy products, produced without thermal processing, as well as direct contact with infected animals, constitute the primary forms of transmission of this bacterium to humans. The inspection service represents an essential tool for the control of this zoonosis (Pinto 2003).

The distribution of BTB across the national territory varies from the different production systems to the sanitary and technological practices employed in each region (Kantor \& Ritacco 2006, Furlanetto et al. 2012). The prevalence of the disease in Brazil is higher in dairy farms, seeing that latest technologies are applied (Acha \& Szyfres 2003, Ferreira Neto et al. 2016). The state of Espírito Santo and the northern regions of São Paulo, southern Minas Gerais, and southern Goiás have the highest BTB prevalence rates in the country, as they concentrate the largest dairy farming (Ferreira Neto et al. 2016). The prevalence of $M$. bovis infecting cattle herds in the state of Rio Grande do Sul (RS) is 2.8\%. The highest rates in this state are also observed in the main milk producing regions (metropolitan area 5.2\%, north region 3.9\%, and mountain range 3.3\%) (Queiroz et al. 2016). Due to the great socioeconomic impact of this disease, the objective of the present study was to carry out an epidemiological analysis of BTB cases, as well as evaluatinge the temporal distribution of this disease diagnosed at LRD of the Faculdade de Veterinária (FV-UFPel) from 2000 to 2015.

\section{MATERIALS AND METHODS}

A survey was carried out in the LRD-UFPel database regarding cases of BTB diagnosed from 2000 to 2015. Necropsy protocols and materials submitted for diagnosis were reviewed. Information regarding breed, sex, and age of animals, as well as presumptive diagnoses, type of material referred for diagnosis, the origin of animals, and month/year of disease occurrence were recorded in Excel spreadsheets and subsequently evaluated. The profile of the affected animals was established through a descriptive statistical analysis of the qualitative variables. In addition, the municipalities of disease occurrence were characterized, it was also checked the efficiency of post mortem examination in identifying macroscopic lesions and the main organs referred for histopathological examination. Incidence rates ([cases/population x 100000]) were calculated by municipality, month and year, after time series analysis from 2002 to 2015 .

Time series. Data were analyzed by evaluating the distribution of BTB cases over time, in order to evaluate possible changes in the behavior of the disease over the years, especially about the incidence rate of tuberculosis and the sensitivity of the information system. LRD-UFPel. The temporal statistical analyses were done by using the Gretl 1.9.12 statistical software (GNU Regression, Econometricand Time-series Library), and an analysis of the existence of the trend and seasonality components was performed by verifying the series and their respective correlograms. Once verified the existence of these components, the series were differentiated and subsequently statistically tested for detecting analysis of stationarity, through increased Dickey-Fuller tests (Dickey \& Fuller 1979), considering a value of $\mathrm{p}<0.05$ (Morettin \& Toloi 2006, Alberti et al. 2018). Once analysis of stationarity was observed in the differentiated series, the presence or absence of the trend and seasonality components in the monthly series considered was inferred. Ordinary Least Squares (OLS) model calculations were performed to estimate the statistically significant trend $(\mathrm{p}<0.05)$, and thecoefficient of determination $\left(\mathrm{R}^{2}\right)$ was calculated based on indicators time-series over time.

In addition, control diagrams were constructed based on the distribution of cases from 2002 to 2015, following the methodology of geometric mean, more appropriate when observing the asymmetric distribution of cases over the years, as described by Bortman (1999). The logarithmic transformation $\left(\log _{10}\right)$ of the original data was performed. Regarding the transformed values, the geometric mean and $95 \%$ confidence intervals (95\% CI) were calculated, which are used as the lower and epidemic endemic limits in the endemic curve (Bortman 1999).

\section{RESULTS}

From 2000 to 2015, 392 samples were sent to the LRD-UFPel with a presumptive diagnosis of tuberculosis, including 305 cases confirmed. In the same period, 23 samples were sent to the 

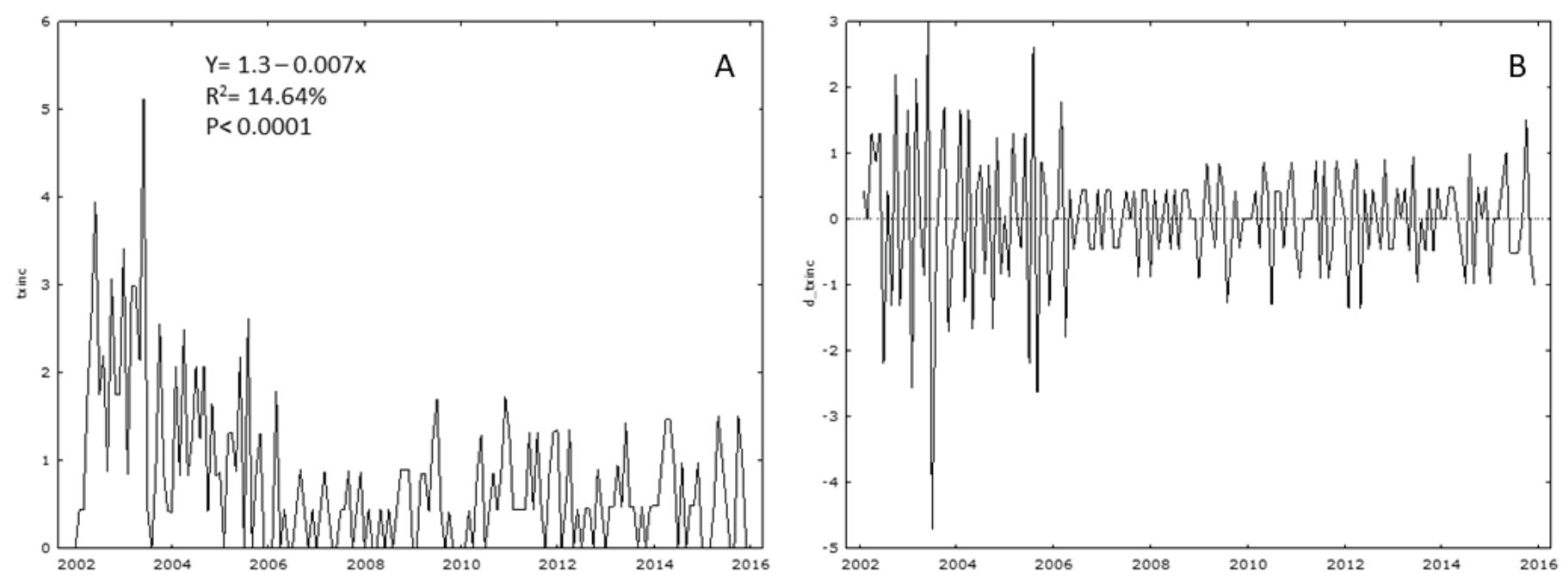

Fig.1 (A-B) Time series and equation of the trend line of the incidence rate of bovine tuberculosis (BTB) (cases/100000 cattle), in the area of "Laboratório Regional de Diagnóstico" (LRD) from the "Faculdade de Veterinária” (FV), "Universidade Federal de Pelotas" (UFPel), Rio Grande do Sul, from 2002 to 2015. (A) Original time series showing a downward trend in the number of cases diagnosed as tuberculosis in cattle in the LRD-FV-UFPel. (B) Differentiated time series (trend free), showing a higher occurrence of tuberculosis from 2002 to 2006.

laboratory without presumptive diagnosis of tuberculosis, and after, another three samples with suspected bovine actinobacillosis, cysticercosis and leukosis were also diagnosed as tuberculosis, consisting of a total of 331 diagnoses of BTB during this period. Considering the $314 / 331(94.86 \%)$ cases of BTB, the samples were sent by the municipal inspection service of Pelotas/RS, which is responsible for inspecting the slaughtering of seven refrigerators in this municipality resulting in 1098 cattle/month. These establishments receive cattle from the municipalities of the micro-region of Pelotas. Field veterinarians referred another 17/331 (5.13\%) cases from different municipalities in the southern region of RS.

Regarding animal profile, 251/331 (75.83\%) animals were older than two years, and 7/331 (2.11\%) younger. Female bovines represented $175 / 331(52.87 \%)$ animals and males $88 / 331$ (26.58\%). In 73/331 (22.05\%) and 68/331 (20.54\%) of the cases, neither age nor gender were not informed. The breed was informed in 178/331 (53.77\%) cases, with predominance of crossbred cattle, mainly with dairy breeds (69/331, 20.84\%), followed by Holstein (46/331, 13.89\%) and Jersey animals $(13 / 331,3.92 \%)$. Among the samples referred for diagnosis, lymph nodes were the most frequent organ sent to analysis $(228 / 331,68.89 \%)$. In 86/331 (25.98\%) cases, together with lymph nodes, organ fragments, such as lung and liver, could be obtained; in 15/331 (4.53\%) corpse, and in $2 / 331(0.6 \%)$ the data was not informed. The main municipalities, where the most animals could be found, were Pelotas (45.32\%), followed by Rio Grande (11.78\%), São Lourenço do Sul (6.95\%), Piratini (6.04\%), Canguçu (5.74\%)) and Capão do Leão (5.45\%).

To assess the time series of the incidence of BTB from 2002 to 2015 , there was a downward trend in the number of cases of this disease $(p<0.05)$ and absence of seasonality $(p<0.05)$ (Fig.1A). The trend graph showed a higher number of cases from 2002 to 2006, with a sharp drop in the occurrence of this disease from 2003 to 2004 (Fig.1B). After comparing the monthly incidence rates obtained over the years concerning the epidemic limit observed in the endemic curve (Fig.2), it

\section{ENDEMIC CURVE}

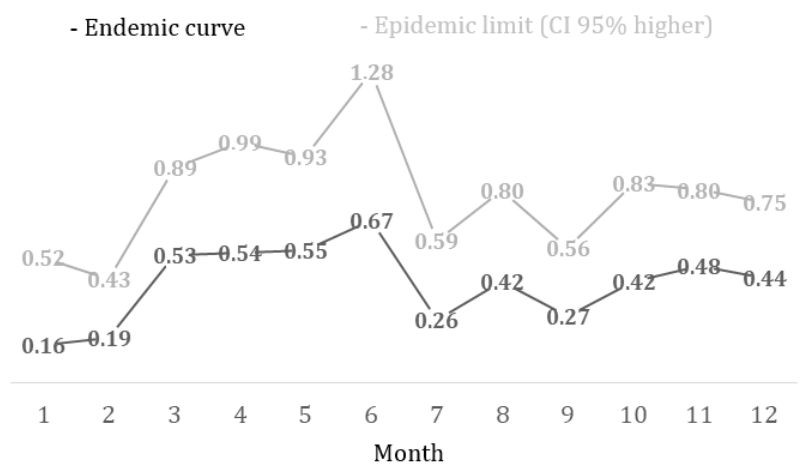

Fig.2. Endemic curve of the incidence rate of bovine tuberculosis (BTB) (cases/100000 cattle), in the area of "Laboratório Regional de Diagnóstico" (LRD) from the "Faculdade de Veterinária" (FV), "Universidade Federal de Pelotas" (UFPel) from 2002 to 2015.

was possible to assess thatthere were no epidemics of BTB in the LRD region, indicating any incidence regarding the epidemic limit proposed by the curve.

\section{DISCUSSION}

In RS, $57.48 \%$ of the cattle herd was classified as beef, and $43.11 \%$ as dairy animals, and this population consists mainly of female bovines over 36 months (38.95\%) (Silva et al. 2014). The predominant profile of the bovines was adult females aged older than two years, crossbred, followed by dairy animals (Holstein and Jersey), and this result corroborated these findings with those observed by Grisi Filho et al. (2011). In a study conducted in the state of Mato do Grosso, the disease was also more frequent in animals older than two years (97.6\%). However, lesions were more prevalent in male bovines $(76.2 \%)$ than in female bovines 
(23.8\%) (Furlanetto et al. 2012), and this fact may be related to the larger population of beef cattle in this state, including an elevate number of male bovine slaughter. According to Humblet et al. (2009), the sex and breed of cattle affected by tuberculosis varied according to the rearing system adopted in each region, and these are not considered risk factors in the occurrence of the disease. However, age is a significant risk factor, as it is directly related to the development of this pathology. Tuberculosis is a disease that affects mainly adult animals, due to its chronic character and higher risk of exposure to the agent over the years (Acha \& Szyfres 2003), which justifies the result of this study, since female bovine animals have a longer productive life longer, staying longer in the properties. The prevalence of tuberculosis is higher in dairy than in beef cattle, due to larger agglomeration of animals in dairy farms, which favors the transmission of the disease; on the other hand, dairy cattle remain in the farms (Acha \& Szyfres 2003, Grisi Filho et al. 2011).

In the present study, regarding the $228 / 331$ cases of BTB, the lymph node was the only organ referred to the laboratory, and in 86/331 cases besides lymph nodes, fragments of other organs, such as lung and liver, were obtained. Souza et al. (2014) evaluated the slaughtering of 140 cattle and among animals, it could be noted that 78 animals presented some type of macroscopic lesion suggestive of tuberculosis infecction, and in 38 cases, the lesions occurred exclusively in the mediastinal lymph nodes, 22 only in the liver, 11 in the lung and seven carcasses presented concomitant lesions in lymph nodes and liver and/or lung. The significant role of lymph nodes in fighting infections is related to the main pathway of mycobacterial infection (respiratory tract). The most frequent lesions occurred in the head, neck, and thoracic cavity lymph nodes (França et al. 2013).

In this study, the presumptive diagnosis of tuberculosis was confirmed in $77.8 \%$ of cases, a result that is similar to that found by Andrade et al. (1991). In $94.86 \%$ of the diagnoses, the samples were sent to seven municipal inspection refrigerators, located in Pelotas. These samples were sent to the LRD-UFPel when the macroscopic lesion did not present typical features of tuberculosis. Slaughterhouses are considered "epidemiological sentinels" in disease control (Baptista et al. 2004), but regarding tuberculosis, only $47 \%$ of lesions are macroscopically detected during post mortem inspection (Corner 1994), due to different stages of the disease and no time for inspection (Souza et al. 2014). The histopathological examination has high sensitivity and specificity in the diagnosis of tuberculosis, being a reliable and fast tool that can help post mortem examination in the diagnosis (Pinto et al. 2004, França et al. 2013), furthermore, it is important to note the differentiation of other diseases detected in macroscopic lesions, such as actinobacillosis (Andrade et al. 1991, Uzal et al. 2016).

According to data from the Ministério da Agricultura, Pecuária e Irrigação (MAPA), Pelotas presented the highest positive number of bovines in tuberculin tests in 2015, including 463 positive results for bovines and an estimated prevalence of $1.35 \%$ (SEAPI 2016). In this study, the incidence of BTB in the LRD-UFPel was evaluated, and a higher rate $(81.28 \%)$ was observed in the municipalities of the micro-region of Pelotas (Pelotas, Rio Grande, São Lourenço do Sul, Piratini, Canguçu, and Capão do Leão). However, this result may be related to the geographic location of the LRD-UFPel, which facilitates the referral of samples for testing by veterinarians of this region, and to the partnership with the municipal inspection service of Pelotas-RS.

According to Ferreira Neto et al. (2016), there was a significant increase (52\%) in the number of BTB in 2015 when compared to 2014 in Brazil. Over the analyzed period, there was a downward trend in the frequency of BTB cases diagnosed in the LRD-UFPel. This downward trend in the number of cases in the LRD-UFPel may be related to an efficiency of the municipal inspection service in recognizing the lesions found during the slaughter. In most cases, a macroscopic diagnosis is made, reducing the total of samples sent to the laboratory for histopathological examination. Another factor that may have influenced this downward trend was the implementation of the "Programa Nacional de Controle e Erradicação da Brucelose e da Tuberculose Animal" (PNCEBT) in 2001, which provided an improvement in the health status of the cattle.

In a study conducted in a slaughterhouse in Nigeria, tuberculosis showed a cyclical behavior (seasonality), with greater occurrence in July and August, differing from the result found in the present study. The authors related this seasonality to stressful factors that occur in this period (off-season) and the increase in the number of religious slaughters (Okeke et al. 2016). The absence of seasonal influence on the occurrence of tuberculosis, observed in the present study, can be explained by the variables, such as: incubation period of the microbiological agent and chronic character of the disease. Thus, the transmission cycle of disease is uncertain to detect, seeing that the disease is diagnosed, in most cases, during the slaughter of the animals. The incidence rate of BTB, according to diagnoses made on the base of LRD-UFPel, did not show an epidemic behavior in this region; since the frequency of the cases remained within the estimated safety zone for the diagnosis same. In the evaluation of the endemic curve, it was also observed that the epidemic limit determined for June is higher and lower in July.

\section{CONCLUSIONS}

The prevalence of tuberculosis diagnosed in the LRD-UFPel from 2000 to 2015 decreased significantly and the profile of affected animals is female bovine, aged over 36 months of age, and dairy cattle, especially crossbred.

Macroscopic identification of lesions during slaughter is efficient since $77.8 \%$ of suspected post mortem examination cases were histologically confirmed as tuberculosis.

During the study period, there were no seasonal and epidemic cycles of the disease in the region.

Conflict of interest statement.- We have no conflict of interest to declare.

\section{REFERENCES}

Acha P.N. \& Szyfres B. 2003. Zoonosis y Enfermidades Transmisibles Comunes al Hombre y a los Animales: bacteriosis y micosis. 3a ed. Vol.1. Organización Panamericana de La Salud, Washington, p.283-299.

Alberti T.S., Bruhn F.R.P., Lansini V., Raffi M.B., Scheid H.V., Zamboni R., Quevedo L. \& Sallis E.S.V. 2018. Occurrence of hydatidosis and cysticercosis in cattle in southern Rio Grande do Sul, Brazil, from 2013 to 2016. Pesq. Vet. Bras. 38(10):1918-1922. <http://dx.doi.org/10.1590/1678-5150-pvb-5865>

Andrade G.B., Riet-Correa F., Mielke P.V., Méndez M.C. \& Schild A.L. 1991. Estudo histológico e isolamento de micobactérias de lesões similares à tuberculose em bovino no Rio Grande do Sul. Pesq. Vet. Bras. 11(3/4):81-86. 
Baptista F., Moreira E.C., Santos W.L.M. \& Naveda L.A.B. 2004. Prevalência da tuberculose em bovinos abatidos em Minas Gerais. Arq. Bras. Med. Vet. Zootec. 56(5):577-580. <http://dx.doi.org/10.1590/S0102-09352004000500002>

Bortman M. 1999. Elaboración de corredores o canales endémicos mediante planillas de cálculo. Pan Am. J. Public Health 5(1):1-8. <http://dx.doi. org/10.1590/S1020-49891999000100001>

Corner L.A. 1994. Post mortem diagnosis of Mycobacterium bovis infection in cattle. Vet. Microbiol. 40(1/2):53-63. <http://dx.doi.org/10.1016/03781135(94)90046-9><PMid:8073629>

Dickey D. \& Fuller W. 1979. Distribution of the estimators for autoregressive time series with a unit root. J. Am. Stat. Assoc. 74(366):427-431. <http:// dx.doi.org/10.2307/2286348>

Ferreira Neto J.S., Silveira G.B., Rosa B.M., Gonçalves V.S.P., Grisi-Filho J.H.H., Amaku M., Dias R.A., Ferreira F., Heinemann M.B., Telles E.O. \& Lage A.P. 2016. Analysis of 15 years of the National Program for the Control and Eradication of Animal Brucellosis and Tuberculosis, Brazil. Semina, Ciênc. Agrárias 37(5):3385-3402.

França L.R., Cruz J.F., Neves V.B.F. \& Cerqueira R.B. 2013. Prevalência e histopatologia de lesões sugestivas de tuberculose em carcaça de bovinos abatidos no Sudoeste da Bahia. Revta Bras. Saúde. Prod. Anim. 14(4):721-733.

Furlanetto L.V., Figueiredo E.E.S., Conte Júnior C.A., Silva F.G.S., Duarte R.S., Silva J.T., Lilenbaum W. \& Paschoalin V.M.F. 2012. Prevalência de tuberculose bovina em animais e rebanhos abatidos em 2009 no estado de Mato Grosso, Brasil. Arq. Bras. Med. Vet. Zootec. 64(2):274-280. <http://dx.doi. org/10.1590/S0102-09352012000200004>

Grisi Filho J.H.H., Rosales C.A.R., Ferreira F., Amaku M., Dias R.A.J.S. \& Ferreira Neto J.S. 2011. Análise epidemiológica das condenações de bovinos por tuberculose em abatedouros do estado de São Paulo. Arqs Inst. Biológico, São Paulo, 78(2):175-181.

Humblet M.F., Boschiroli M.L. \& Saegerman C. 2009. Classification of worldwide bovine tuberculosis risk factors in cattle: a stratified approach. Vet. Res. 40(5):50. <http://dx.doi.org/10.1051/vetres/2009033><PMid:19497258>

Kantor I.N. \& Ritacco V. 2006. An update on bovine tuberculosis programmes in Latin American and Caribbean countries. Vet Microbiol. 112(2/4):111118. <http://dx.doi.org/10.1016/j.vetmic.2005.11.033><PMid:16310980>

López A. 2013. Sistema respiratório, mediastino e pleuras, p.463-558. In: McGavin M.D. \& Zachary J.F. (Eds), Bases da Patologia em Veterinária. 5a ed. Elsevier, Rio de Janeiro.

Morettin P.A. \& Toloi C.M.C. 2006. Análise de Séries Temporais. 2ed. Edgard Blucher, São Paulo. 729p.

Okeke L.A., Fawole O., Muhammad M., Okeke I.O., Nguku P., Wasswa P., Dairo D. \& Cadmus S. 2016. Bovine tuberculosis: a retrospective study at Jos abattoir, Plateau State, Nigeria. Pan Afr. Med. J. 25:1-6. <http://dx.doi. org/10.11604/pamj.2016.25.202.5669><PMid:28292159>

Perez A.M., Ward M.P., Torres P. \& Ritacco V. 2002. Use of spatial statistics and monitoring data to identify clustering of bovine tuberculosis in
Argentina. Prev. Vet. Med. 56(1):63-74. <http://dx.doi.org/10.1016/ S0167-5877(02)00124-1><PMid:12419600>

Pinto P.S.A. 2003. Atualização em controle da tuberculose no contexto da inspeção de carnes. Biosci. J. 19(1):115-121.

Pinto P.S.A., Viloria M.I.V., Faria J.E. \& Almeida L.P. 2004. Avaliação do desempenho dos exames anatomopatológico e histopatológico na inspeção post mortem de bovinos suspeitos ou reagentes à prova de tuberculinização. Revta Bras. Ciênc. Vet. 11(1/2):27-31.

Prasad H.K., Singhal A., Mishra A., Shah N.P., Katoch V.M., Thakral S.S., Singh D.V., Chumber S., Bal S., Aggarwal S., Padma M.V., Kumar S., Singh M.K. \& Acharya S.K. 2005. Bovine tuberculosis in India: Potential basis for zoonosis. Tuberculosis 85(5/6):421-428. <http://dx.doi.org/10.1016/j. tube.2005.08.005><PMid:16253560>

Queiroz M.R., Groff A.C.M., Silva N.S., Grisi-Filho J.H.H., Amaku M., Dias R.A., Telles E.O., Heinemann M.B., Neto J.S.F., Gonçalves V.S.P. \& Ferreira F. 2016. Epidemiological status of bovine tuberculosis in the state of Rio Grande do Sul, Brazil. Semina, Ciênc. Agrárias 37(5):3647-3658.

Riet-Correa F. \& Garcia M. 2007. Tuberculose, p.432-442. In. Riet-Correa F, Schild A.L., Lemos R.A.A. \& Borges J.R.J. (Eds), Doenças de Ruminantes e Equinos. Vol.1. 3ㄹa ed. Varela, São Paulo.

Rocha V.C.F., Figueiredo S.C., Elias A.O., Leão D.A.S. \& Ferreira Neto J.S. 2012. Mycobacterium bovis como agente causal da tuberculose humana. Revta Educ. Cont. Vet. Med. Zootec. 10(2):22-31. <http://dx.doi.org/10.36440/ recmvz.v10i2/3.252>

Schiller I., RayWaters W., Vordermeier H.M., Jemmi T., Welsh M., Keck N., Whelan A., Gormley E., Boschiroli M.L., Moyen J.L., Vela C., Cagiola M., Buddle B.M., Palmer M., Thacker T. \& Oesch B. 2011. Bovine tuberculosis in Europe from the perspective of an officially tuberculosis free country: trade, surveillance and diagnostics. Vet. Microbiol. 151(1/2):153-159. <http://dx.doi.org/10.1016/j.vetmic.2011.02.039><PMid:21439740>

SEAPI 2016. Relatório Anual de Atividades de Controle da Tuberculose e Brucelose no Rio Grande do Sul. Secretaria da Agricultura, Pecuária e Irrigação (SEAPI), Porto Alegre, RS.

Silva G.S., Costa E., Bernardo F.A., Groff F.H.S., Todeschini B., Santos D.V. \& Machado G. 2014. Panorama da bovinocultura no Rio Grande do Sul. Acta Scient. Vet. 42:1-7.

Souza M.A., Bombonato N.G., Soares P.M., Ramos G.B., Santos M.P., Ganda M.R. \& Lima-Ribeiro A.M.C. 2014. Frequência de lesões macroscópicas em carcaças de bovinos reagentes ao teste tuberculínico. Arqs Inst. Biológico, São Paulo, 81(4):363-367.<https://doi.org/10.1590/1808-1657000402013>

Uzal F.A., Plattner B.L. \& Hostetter J.M. 2016. Alimentary system, p.1-257. In: Maxie G. (Ed.), Jubb, Kennedy and Palmer's Pathology of Domestic Animals. Vol.2. 6 ${ }^{\mathrm{a}}$ ed. Elsevier, St Louis. <http://dx.doi.org/10.1016/ B978-0-7020-5318-4.00007-3> 